\title{
23(b)(2) Class Certification: Choosing an Approach for Certifying Civil Rights Discrimination Class ACTION SuITS
}

\author{
James T. Tsai
}

\begin{abstract}
The passage of the 1991 amendments to the Civil Rights Act granted injunctive as well as monetary damages for impermissible discrimination in the workplace. The Act also created a tension with the last revision of the Federal Rules of Civil Procedure in 1966. This revision prohibits the certification of a class under Rule 23(b)(2) if the damages sought are predominantly monetary in nature. On one end of this resulting tension is the desire to protect individuals rights to "opt-out" of a class action suit and maintain future individual actions. On the other end is the desire for judicial economy and the possibility to have sweeping remedies in the form of injunctive or declaratory relief. This tension is not reconcilable at the present and has fueled the growth of a three-way circuit split over what standard should be used to decide the certification of a class action civil rights discrimination suit. I argue that the circuit split has presented some courts to provide a higher burden to alleged victims of civil rights discrimination, in direct frustration of Congress' legislative intent to compensate victims and give a punitive remedy against large companies that commit civil rights violations. I propose a burden-shifting solution to the circuit split that takes into account the interests of the parties in a class action suit as well as the effects of racial politics. I however advocate an appropriate and ultimate solution that revises the Federal Rule that clearly expresses an approach taking into account this tension.
\end{abstract}




\section{Table of Contents}

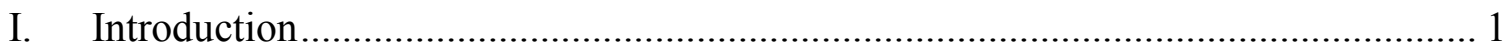

II. The existing different tests for determining 23(b)(2) certification ........................... 3

A. Dominant approach: Allison and the incidental damages approach (Fifth Circuit) 4

B. Ad hoc balancing approach (Second Circuit) .............................................. 7

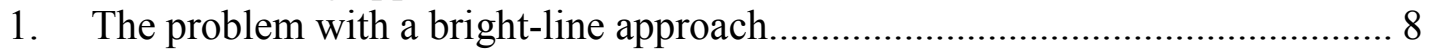

2. The problem with absent class members ..................................................... 9

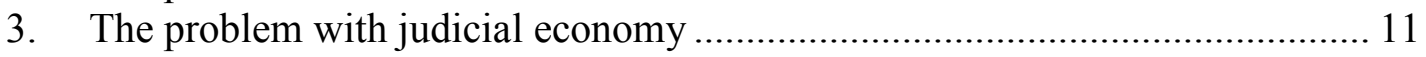

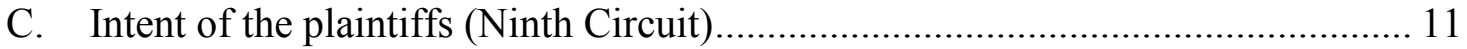

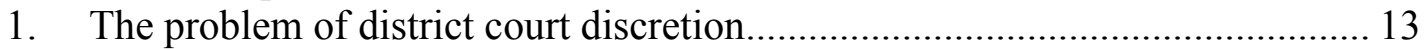

2. The problem of the future of "civil rights litigation" and "predominance"...... 14

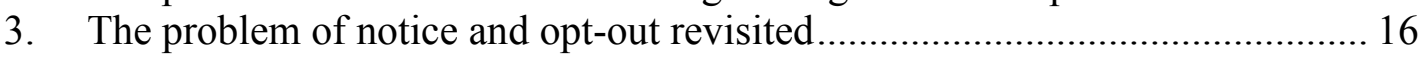

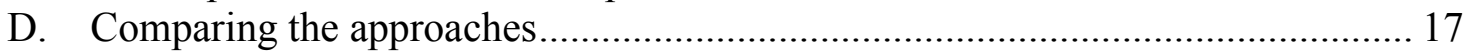

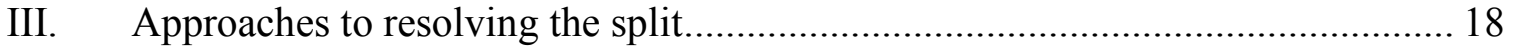

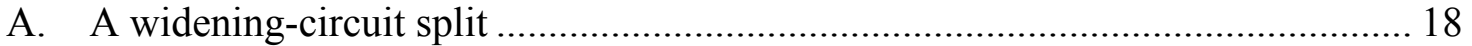

B. Balancing the competing goals of the Civil Rights Act of 1991 and the Class

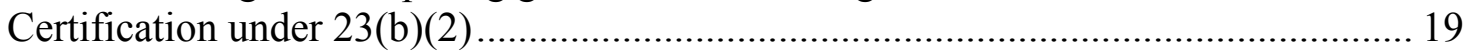

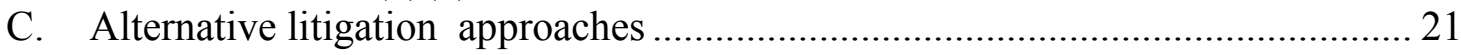

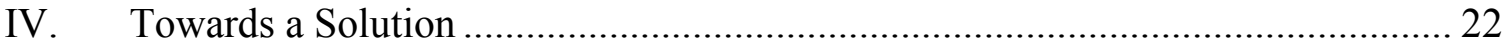

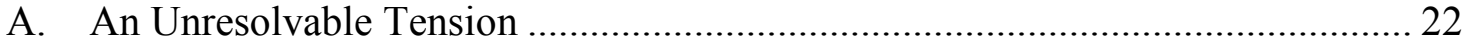

B. A heightened pleading framework ........................................................... 22

1. Objective prong: No reasonable potential class member would wish to be

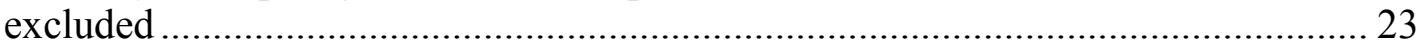

2. Subjective prong: The intent of the plaintiffs .......................................... 24

C. Benefits of the proposed approach.................................................................. 25

D. Problems of the proposed approach ................................................................ 25

1. Heightened pleading at too early a stage in litigation................................. 25

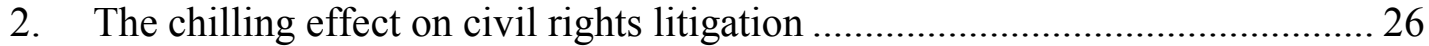

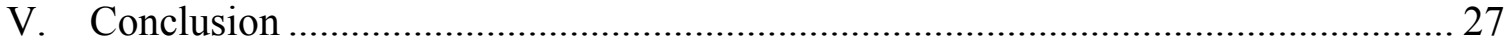




\title{
23(b)(2) Class Certification: Choosing an Approach for Certifying Civil Rights Discrimination Class ACTION SuIts ${ }^{1}$
}

\author{
James T. Tsai ${ }^{2}$
}

\section{Introduction}

Civil rights discrimination claims may be brought as a class action suit. Under the Federal Rules of Civil Procedures, there are two relevant methods that allow a class action to be maintained. ${ }^{3}$ Under Rule 23(b)(2), injunctive or declaratory relief may be granted to a class when the "party opposing the class has acted or refused to act on grounds generally applicable to the class." Compared to Rule 23(b)(3), monetary damages are appropriate after various factors are considered.

There is an existing circuit split regarding when a civil rights discrimination case arises and is to be certified as a class. It asks which part of Rule 23 is appropriate? At the heart of the issue is whether plaintiffs may claim a mixture of both injunctive relief and monetary relief in class certification for a claim of civil rights discrimination. The Advisory Committee Notes state that Rule 23(b)(2) certification "does not extend to cases in which the appropriate final relief relates exclusively or predominately to money damages."4 Three different standards have arisen as to when to certify these class action suits. The dominant approach comes from Allison v. Citgo, which specified a bright-line approach by using an incidental damages test. ${ }^{5}$

\footnotetext{
${ }^{1}$ Written for Prof. William Carter's Civil Rights Seminar Class, Fall 2006 at Case Western Reserve University School of Law.

2 J.D. Candidate 2007, B.S. Univ. of Virginia, 2001.

${ }^{3}$ The Federal Rules of Civil Procedures ("Rules") are frequently revised. The latest revision at the time of the writing of this note was in 2006. There were no changes to the class action suits. Congress did pass the Class Action Fariness Act (CAFA) in 2005 however, but these changes do not affect the scope of the issues in this note.

${ }^{4}$ Notes of Advisory Committee on 1966 Amendments to Rules, Rule 26(b)(2).

5 151 F.3d 402 (5th Cir. 1998).
} 
The Civil Rights Act amendments of 1991 (the "Civil Rights Act") allowed both injunctive as well as monetary damages to be sought. ${ }^{6}$ This consequently affected the class certification analysis in employee discrimination cases. ${ }^{7}$

Class action suits serve a wider purpose than just judicial efficiency; they also provide egalitarian justice to members of a class that are similarly situated. In the case of 23(b)(2) class action certifications, several issues arise. Amongst them is the problem with injunctive and declaratory relief being mixed with monetary relief; a second issue arises out of due process concerns with notice and the possibility to opt-in or opt-out of a massive class action.

It is not disputed that class action suits for civil rights discrimination cases can be beneficial. All the same reasons to allow a class action suit to be certified and to proceed apply. Among them are judicial efficiency, the need to have uniform judgments and adjudications for parties and effective justice. Some additional benefits from class action suits may apply though. For instance, a class action suit may achieve more profile and more publicity than a simple loneplaintiff case. Because of the particularly onerous and invidious nature of civil rights employment discrimination, the use of a class action suit may aid in this particular goal.

This note addresses the current tension between the requirements of Rule 23(b)(2) in restricting civil rights discrimination class actions suits seeking monetary damages and the express grant given in the Civil Rights Act of 1991 for monetary damages. First, the background regarding how different circuits have attempted to resolve the split is described. Next, the policy reasons for each of class actions in general as well as underlying rationales for the restrictions in Rule 23 are discussed. Finally, I propose a burden-shifting framework to resolve the circuit split.

\footnotetext{
${ }^{6}$ Pub.L. No. 102-66, 105 Stat. 1071 (1991); codified at 42 U.S.C. $\$ 2000$ e et seq.

${ }^{7}$ See generally Daneil F. Piar, The Uncertain Future of Title VII Class Actions After the Civil Rights Act of 1991, 2001 BYU L. REV. 305 (2001).
} 


\section{The existing different tests for determining 23(b)(2) certification}

When a class action case comes before a federal district court, the court must "at an early practicable time, determine by order whether to certify the action as a class action." 8 To consider certification the court looks to preliminary requirements in Rule $23(\mathrm{a})^{9}$, the gatekeeper function for class actions. It states:

One or more members of a class may sue or be sued as representative parties on behalf of all only if (1) the class is so numerous that joinder of all members is impracticable, (2) there are questions of law or fact common to the class, (3) the claims or defenses of the representative parties are typical of the claims or defenses of the class, and (4) the representative parties will fairly and adequately protect the interests of the class. ${ }^{10}$

These elements reflect general principles for having class action cases. After this initial hurdle is overcome, the class may be certified under one of the three options of 23(b). 23(b)(1) offers certification in cases where there is a risk of either impairment of other judgments for the opposing class due to varying adjudications ${ }^{11}$ or a risk for absent members that would have their own interests impeded by not having a class action suit. ${ }^{12}$ Courts have recognized Rule 23(b)(1) as seeks to impede these risks. ${ }^{13}$

\footnotetext{
${ }^{8}$ Fed. R. Civ. P. 23(c)(1)(A) (as amended in 2003).

${ }^{9}$ Fed. R. Civ. P. 23(a).

${ }^{10} I d$. There are additional requirements preliminarily of course, such as the need for the genuine existence of the class, the representative

${ }^{11}$ Fed. R. Civ. P. 23(a)(1).

${ }^{12}$ Fed. R. Civ. P. 23(a)(2).

${ }^{13}$ See e.g. Ortiz v. Fibreboard Corp., 527 U.S. 815, 833-35 (1999) (giving examples of appropriate 23(b)(1) actions).
} 
Rule 23(b)(3) is the most popular vehicle for class action certification. ${ }^{14}$ It reads like a residual option, catching any situations, where "the questions of law or fact are common to the members and that a class action is superior to other available methods for the fair and efficient adjudication of the controversy." ${ }^{15}$ Certification under 23(b)(3) however comes with cost: it requires notice to all putative members, giving them the right to opt-out of the class litigation, ${ }^{16}$ as well as a multi-factor test to gain certification. ${ }^{17}$

This leaves 23(b)(2), which has the least text of the three certification options, but arguably is causing the most headache, at least certainly in the civil rights employment context. The remainder of this Part discusses the different approaches to deciding whether a court should grant certification under 23(b)(2). It considers the courts' reasoning and rationale for articulating its approach, specifically focusing on the criticisms of other approaches. Some analysis is also given regarding the effects on public policy concerns underlying class action suits.

\section{A. Dominant approach: Allison and the incidental damages approach (Fifth Circuit)}

James E. Allison was one of originally more than a thousand plaintiffs who sued Citgo, a petroleum company in a class action. ${ }^{18}$ The original request for certification sought to challenge the legality of "promotions/pay, hiring/pay, testing, and training policies and procedures of Citgo which they claim are racially discriminatory on a classwide basis. ${ }^{, 19}$ The complaint also claimed there was a racially hostile work environment. ${ }^{20}$ The magistrate judge that heard the case denied

\footnotetext{
${ }^{14}$ Gene R. Shreve \& Peter Raven-Hansen, Understanding Civil Procedure $§ 9.09$ n 214 (3d ed.2002).

${ }^{15}$ Fed. R. Civ. P. 23(b)(3).

${ }^{16}$ Fed. R. Civ. P. 23(c)(2)(B).

${ }^{17}$ Fed. R. Civ. P. 23(b)(3). The Rule suggests at least four factors to consider: "(A) the interest of members of the class in individually controlling the prosecution or defense of separate actions; (B) the extent and nature of any litigation concerning the controversy already commenced by or against members of the class; (C) the desirability or undesirability of concentrating the litigation of the claims in the particular forum; (D) the difficulties likely to be encountered in the management of a class action." Id.

${ }^{18}$ Celestine v. Citgo Petroleum Corp., 165 F.R.D. 463, 465 (W.D.La.,1995).

${ }^{19} \mathrm{Id}$.

${ }^{20} I d$.
} 
certification of the class on the grounds that money damages were the predominant form of relief sought. ${ }^{21}$

Federal Rule of Civil Procedure 23(b)(2) notes that:

(b) Class Actions Maintainable. An action may be maintained as a class action if the prerequisites of subdivision (a) are satisfied, and in addition ... (2) the party opposing the class has acted or refused to act on grounds generally applicable to the class, thereby making appropriate final injunctive relief or corresponding declaratory relief with respect to the class as a whole.

On the mind of the drafters for an appropriate situation needing injunctive or declaratory relief were civil rights suits. ${ }^{22}$ But they also cryptically noted that (b)(2) "does not extend to cases in which the appropriate final relief relates exclusively or predominantly to money damages. ${ }^{, 23}$ There is no further guidance as to what predominant may mean. Is it a quantitative analysis? Is it subjective or objectively reasoned?

The Fifth Circuit considered the issue in the face of rising class action suits against businesses $^{24}$ and created a test focusing on the monetary damages and its relation to the injunctive relief. This approach asserts that "claims for ... monetary relief predominate unless they are incidental to related claims for injunctive or declaratory relief." 25 This language suggests a presumption that monetary relief will be predominant at the outset; there needs to be a showing that the relief is only "incidental." The Allison court defines incidental damages as "damages that

\footnotetext{
${ }^{21} I d$. at 46

${ }^{22}$ Notes of Advisory Committee on 1966 Amendments to Rules, Rule 26(b)(2). (noting that "[i]llustrative are various actions in the civil-rights field where a party is charged with discriminating unlawfully against a class, usually one whose members are incapable of specific enumeration.")

${ }^{23} I d$.

${ }^{24}$ See Nikaa Baugh Jordan, Allison v. Citgo Petroleum: The Death Knell for the Title VII Class Action?, 51 ALA. L. REV. 847, 847 (2000) (noting the doubling of such suits between 1992 and 1997).

${ }^{25}$ Allison v. Citgo, 151 F.3d 402, 425 (1998).
} 
flow directly from liability to the class as a whole on claims forming the basis of the injunctive or declaratory relief.,"26

Though this language seems a bit unclear, the majority explained its reasoning, giving a hint as to how it arrived its formulated test. "Ideally, incidental damages should be only those to which class members automatically would be entitled once liability to the class (or subclass) as a whole is established." 27 The court draws this from the language of 23(b)(2), which notes relief as appropriate "with respect to the class as a whole." ${ }^{28}$ From this principle, the court describes a series of characteristics that would satisfy this test.

The first characteristic is that the damages "should typically be concomitant with, not merely consequential to class-wide injunctive to, class-wide injunctive or declaratory relief."29 Though the Allison court does not give further guidance on what this means in Allison or subsequent cases, other courts have adopted the language wholesale and referred to it. ${ }^{30}$

The next characteristic deals with how the damages should be calculated. The calculations means should be capable by means of objective standards. ${ }^{31}$ Additionally, this calculation should not be dependent "in any significant way on the intangible, subjective differences of each class member's circumstances." 32 The court specifically mentions the use of separate hearings of individual members to determine what damages and amounts to award them as examples that would violate this characteristic. ${ }^{33}$

${ }^{26} I d$.

${ }^{27}$ Id. at 415 .

${ }^{28}$ Fed. R. Civ. P. 23(b)(2) (emphasis added).

${ }^{29}$ Allison, 151 F.3d at 415.

${ }^{30}$ See e.g. Reeb v. Ohio Dept. of Rehab. and Corr., 435 F.3d 639, 650 (6th Cir. 2006) (quoting the language about concomitant damages with no additional explanation).

${ }^{31}$ Allison v. Citgo, 151 F.3d 402, 415 (1998).

${ }^{32} \mathrm{Id}$.

${ }^{33} I d$. 
Despite these characteristics, the court tried to distinguish the test with permitting back pay under Title VII claims in 23(b)(2) class actions. The important distinguishing characteristic in those situations is that the back pay owed to the plaintiff was for equitable remedy purposes. ${ }^{34}$ Citing a controlling case in the Fifth Circuit as an example of this back pay as equitable relief, the court noted that the only claims in Pettaway v. American Cast Iron Pipe Co., ${ }^{35}$ were for equitable monetary relief; the case was silent on compensatory and punitive damages, so the question of applicability of 23(b)(2) to these damages has not been resolved. ${ }^{36}$

Finally, the Allison court admits that the inquiry into whether or 23(b)(2) may be granted is one of discretion that applies this test; it is one that is complex, but the courts are best suited for it. ${ }^{37}$

The incidental damages test is set to stay in the Fifth Circuit; it has been affirmed at least six times. ${ }^{38}$ Several other circuits have adopted this approach, making it the leading approach in the various circuits ${ }^{39}$

\section{B. Ad hoc balancing approach (Second Circuit)}

In 2001, the Second Circuit confronted the same issue in Robinson v. Metro-North Commuter $^{40}$ but decided to reject the Allison court's approach and come up with its own test. The lawsuit sought to certify approximately 1,300 African-Americans that had worked for the defendant, a corporation that provides commuter rail transportation between New York City and

\footnotetext{
${ }^{34} I d$.

${ }^{35} 494$ F.2d 211 (5th Cir. 1974).

${ }^{36}$ Allison v. Citgo, 151 F.3d 402, 415-16 (1998).

${ }^{37} \mathrm{Id}$. at 416.

${ }^{38}$ Joel S. Feldman \& Laura D. Warren, 2(b) or not 2(b): When Can a 23(b)(2) Injunctive Class Be Certified?, 744 PLI LIT. 637, 646 (2006) (citing cases).

${ }^{39}$ In the Third Circuit, Barabin v. Aramark Corp., No. 02-8057, 2003 WL 35417 (3d Cir. Jan 24, 2003); in the Sixth Circuit, Reeb v. Ohio Dept. of Rehab. and Corr. , 435 F.3d 639, 650 (6th Cir. 2006); in the Seventh Circuit, In Re Allstate Insurance Co,m 400 F.3d 505, (7th Cir. 2005); and in the Eleventh Circuit, Cooper v. Southern Company, 390 F.3d 695 (11th Cir. 2004).

40267 F.3d 147 (2d Cir 2001), cert. denied 535 U.S. 951 (2002).
} 
the northern suburbs. ${ }^{41}$ The plaintiffs claimed discrimination based on both pattern-or-practice disparate treatment as well as disparate impact, both pursuant to Title VII of the Civil Rights Act. ${ }^{42}$ There was no request for punitive damages. ${ }^{43}$ The Robinson court explicitly rejected the Allison court's approach declining a bright-line approach in favor of an ad hoc balancing approach. ${ }^{44}$ It articulated a two-step test: a district court may allow 23(b)(2) certification if (1) "the positive weight or value [to the plaintiffs] of the injunctive or declaratory relief sought is predominant even though compensatory or punitive damages are also claimed" and (2) class treatment would be efficient and manageable, thereby achieving an appreciable measure of judicial economy. ${ }^{45}$ This test was adjudged to be a better approach than the bright-line approach of Allison because of several policy concerns it reasoned out from considering the end-result of a bright-line test and also the needs of judicial economy and fairness to absent class members.

1. The problem with a bright-line approach

The court began by noting that the question of whether relief sought involving money damages precludes 23(b)(2) certification was one of first impression in the circuit. ${ }^{46}$ The district court's application of the Allison incidental-damages was done because there was no clear standard "discernible from either the text of Rule 23(b)(2) or our circuit precedent."

In the end, the Robinson court articulated a balancing approach that takes into account various factors, such as the importance of the remedies sought, "given all of the facts and circumstances of the case." ${ }^{, 48}$ This totality of the circumstances approach is favorable according

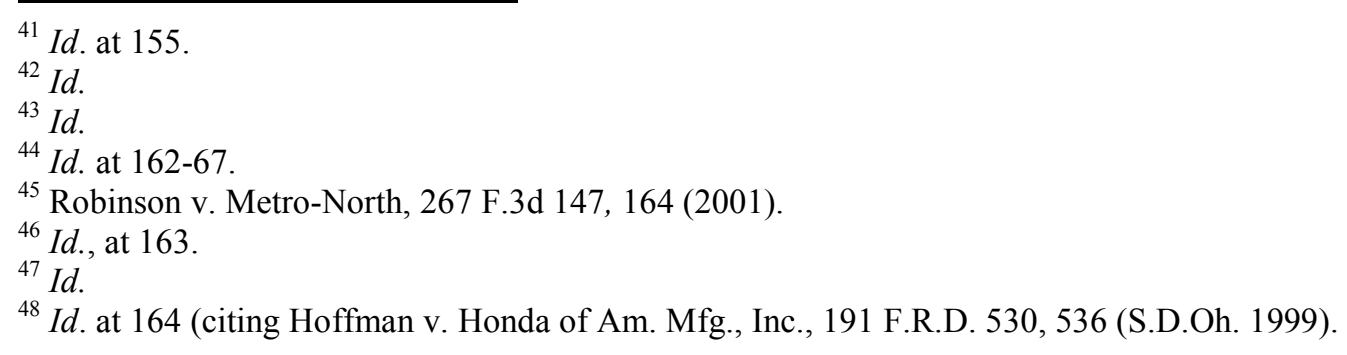


to the Robinson Court because it still achieves the Allison court's goals of judicial economy and ensuring due process still is available for the absent class members. ${ }^{49}$

It arrived at this approach by noting the unfortunate consequence of a bright-line approach: compensatory or punitive damages would fail the computation characteristic of the Allison test. ${ }^{50}$ That is, the very nature of the claims would differ from plaintiff to plaintiff and there would need to be special consideration for each situation, therefore failing the incidentaldamages test and barring 23(b)(2) certification. The Robinson court arrives at this finding recognizing the Allison court's reasoning and acknowledgement that back pay would still be permissible as a form of remedy, while noting that compensatory damages from "emotional pain, suffering, inconvenience, mental anguish, loss of enjoyment of life, [or] other nonpecuniary losses" would have to be determined on an individual basis, during the same phase to determine the equitable relief for each plaintiff. ${ }^{51}$

\section{The problem with absent class members}

An underlying problem of 23(b)(2) certification is the effect it has on absent class members. As a D.C. Circuit court described it, the assumption that 23(b)(2) class members, "suffer from a common injury that can be addressed by class-wide relief - begins to break down when the class seeks to recover back pay or other forms of monetary damages to be allocated based on individual injuries." ${ }^{52}$ The Robinson court also acknowledged this, admitting that absent class members may have their interests unprotected in a 23(b)(2) proceeding. ${ }^{53}$

\footnotetext{
${ }^{49} I d$. at 165 .

${ }^{50} \mathrm{Id}$. at 164.

${ }^{51}$ Robinson v. Metro-North, 267 F.3d 147, 160 (2001).

52 Eubanks v. Billington, 110 F.3d 87, 95 (D.C. Cir. 1997).

${ }^{53}$ Robinson v. Metro-North, 267 F.3d 147, 164-65 (2001). "The presumption of class homogeneity and cohesion falters, and thus, adequate representation alone may prove insufficient to protect absent class members interests" when nonincidental damages are sought under Rule 23(b)(2)).
} 
The problem specifically deals with the opportunity for an absent member to exclude themselves from litigation. In Phillips Petroleum Co. v. Shutts, the Supreme Court pointed out constitutional due process problems when "an absent plaintiff [does not have] an opportunity to remove himself from the class by executing and returning an 'opt out' or 'request for exclusion' form to the court," when monetary damages are sought. ${ }^{54}$

23(b)(2) differs from 23(b)(1) and 23(b)(3) certification most notably with the lack of a requirement of notice to all potential class members. Substantively, due process rights of absent members are important for the purposes of being able to opt-out of potential litigation. The Robinson court addressed the problem by noting that absent members could still have their due process rights met by having the district court give notice and opt out rights to "absent class members for those portions of the proceedings where the presumption of class cohesion falters i.e. the damages phase of the proceedings." ${ }^{, 55}$ The court relied on a presumption that class members' goals and interests are essentially identical in certain phases of the litigation, and where they do differ, the court would be able to solve the problem by giving notice and opt-out opportunity. ${ }^{56}$ The court also notes that this presumption actually safeguards absent class members' interests, satisfying the needs of due process. ${ }^{57}$

Arguably, this presumption is valid for the genre of civil rights employment discrimination cases. Employees of a company may be identified based on company records during a phase of litigation where their specific difference needs to be addressed. This would most likely be in the remedial stage, at the end of the litigation phase; but for the purposes of certification, their interests are all the same at the moment - to stop civil rights discrimination

\footnotetext{
${ }^{54}$ Phillips Petroleum Corp. v. Shutts, 472 U.S. 797 (1985).

${ }^{55}$ Robinson, 267 F.3d at 166.

${ }^{56} \mathrm{See} i \mathrm{id}$. at $\mathrm{n} .10$ (expressing the liability phase of a pattern-or-practice discrimination case and the class-wide phases of a disparate impact claim would have identical goals for all class members).

${ }^{57}$ Id. at 165 (citing Johnson v. Gen. Motors Corp, 598 F.2d 432, 437 (5th Cir.1979)).
} 
from taking place. The counterargument to this presumption is identified by the Robinson court themselves. They acknowledge that there is still a due process risk, and the Allison bright-line approach completely eliminates the risk. ${ }^{58}$

The point of issue between Allison and Robinson on this due process issue may simply boil down to a question of risk adversity. If there is a remote risk of due process violation, the Allison court would simply deny certification; the Robinson court believes that the risk is mitigated by presuming class interests are cohesive at certain stages of litigation and at the points where they do differ, the due process rights may be saved by the court's intervention. ${ }^{59}$

\section{The problem with judicial economy}

The Robinson court disposes this concern in one sentence in its opinion; a "case-by-base basis is superior to the one-size fits all approach of the incidental damages standard." ${ }^{60}$ The Allison court had instead argued that the very goals of class action were to allow for judicial economy. ${ }^{61}$ Complex calculation "typically required" for money damages in class actions would hinder this goal. ${ }^{62}$

At odds between the two courts is the public policy question of how judicial resources should be allocated. The Class Action Fairness Act of 2005 (CAFA) recognized that there had been an increase in the number of abusive uses of class action suits in the past decade before it was passed. ${ }^{63}$ The abuses result in a burden on the judicial system. ${ }^{64}$

\section{Intent of the plaintiffs (Ninth Circuit)}

\footnotetext{
${ }^{58} I d$. at 166.

${ }^{59}$ The district court may direct the "appropriate notice" to any 23(b)(2) certified classes. Fed. R. Civ. P. 23(c)(2)(A).

${ }^{60}$ Robinson v. Metro-North, 267 F.3d 147, 165 (2001).

${ }^{61}$ Allison v. Citgo, 151 F.3d 402, 414 (1998).

${ }^{62} \mathrm{Id}$.

${ }^{63}$ Class Action Fairness Act of 2005, Pub. L. No. 109- 2, §2(a)(2), 119 Stat 4, 4 (2005) [hereinafter CAFA].

${ }^{64} I d$. at $\S 4$.
} 
In 2003, just two years after the Robinson court handed down its opinion, the Ninth Circuit also rejected the Allison test and decided to formulate its own in Molski v. Gleich ${ }^{65}$ The Molski court echoed the Robinson court's concern that the adoption of a bright-line rule would "nullify the discretion vested in the district courts through Rule 23." ${ }^{, 66}$ In the end, the court decided that the most important consideration was to ask what the "intent of the plaintiffs in bringing the suit" was. ${ }^{67}$

The Molski case is not an employment discrimination class action case, but instead involves denial of access to public accommodations and discrimination under the Americans with Disabilities Act. ${ }^{68}$ Jarek Molski, was a paraplegic law school graduate that has filed more than 200 lawsuits alleging violation of disability rights laws in the state of California. ${ }^{69}$ One of his earlier cases sued ARCO, a corporation that owns, leases and operates approximately 1,200 gas stations and mini-markets in California. ${ }^{70}$

Molski originally filed the complaint as a sole plaintiff. After a series of settlement negotiations, the parties agreed to a consent decrees, that included payment of $\$ 195,000$ to disability rights organizations, $\$ 50,000$ in attorney's fees and $\$ 5,000$ in damages to Molski. ${ }^{71}$ Following this negotiation, the complaint was amended to create a class and the consent decree was submitted for approval by the district court. The court directed that notice should be given in the form of posters at the ARCO properties, publication in major newspapers throughout

\footnotetext{
${ }^{65}$ Molski v. Gleich, 318 F.2d 937 (9th Cir. 2003); but see Natasha Dasani, Class Actions and the Interpretation of Monetary Damages Under Federal Rule of Civil Procedure 23(b)(2), 75 Fordham L. Rev. 165, 175 (2006) (describing the Molski court as adopting the Robinson court's approach, rather than creating its own test).

${ }^{66} I d$. at 950 .

${ }^{67} I d$.

${ }^{68}$ Id. at 941; Americans With Disabilities Act, 42 U.S.C. $\$ 12101$ et seq.

${ }^{69}$ Marjie Lundstrom \& Sam Stanton, "Visionary law's litigious legacy," SACRAMENTO BEE (Nov. 12, 2006).

${ }^{70}$ Molski v. Gleich, 318 F.2d 937, 941 (9th Cir. 2003).

${ }^{71} I d$. at 942.
} 
California and mailing of notice to over 80 disability rights organizations in California. ${ }^{72} \mathrm{~A}$ deadline was also set for opting out of the class or filing objections to the proposed consent decree. ${ }^{73}$ Of the objections that were eventually filed most dealt with the decree's release of state statutory damages, while some expressed concern over the adequacy of the injunctive relief provided. $^{74}$

When the district court certified the class under Rule 23(b)(2) and approved the consent decree, various parties appealed on several issues. ${ }^{75}$ In considering whether the class was properly certified, the Molski court arrived at its formulation of looking at the intent of the parties to determine whether or not certification is appropriate. The Molski court seemed to adopt many of the concerns the Robinson court had, agreeing that the damages in the consent degree would have failed the Allison incidental damages test, ${ }^{76}$ but rejected the bright-line approach because of three main problems: infringement on the district court's discretion, the future of civil rights litigation and the question of defining what "predominant" means within Rule 23(b)(2)'s Advisory Note. ${ }^{77}$ The court also considered the issue of notice and opt-out as a completely separate issue. $^{78}$

1. The problem of district court discretion

Judge Dennis wrote the dissenting opinion in Allison. The Molski court cited his dissent, noting that a bright-line test that distinguished, "between incidental and nonincidental damages for the purposes of determining predominance would nullify the discretion vested in the district

\footnotetext{
${ }^{72} I d$.

${ }^{73} \mathrm{Id}$.

${ }^{74} \mathrm{Id}$.

${ }^{75}$ Molski v. Gleich, 318 F.2d 937, 942 (9th Cir. 2003).

${ }^{76} I d$. at 949.

${ }^{77} \mathrm{Id}$. at $949-50$.

${ }^{78} \mathrm{Id}$. at $946-49$.
} 
courts through Rule 23." ${ }^{, 79}$ The hallmark case that describes the discretionary role of courts with respect to Rule 23 is Gold Strike Stamp Co. v. Christensen.$^{80}$ Although the case was an antitrust class action case, involving an unusual filing of a writ of mandamus against the trial judge for class certification, the principle the court articulated was clear: the trial court has discretion in applying Rule $23 .^{81}$

This disagreement once again is a question of public policy between the needs of reducing risk and increasing judicial efficiency versus allowing civil rights cases to proceed and here the need to allow for judicial discretion. The Molski court seems to be concerned with the equitable function that courts are supposed to provide in providing justice. This relates to the next problem the Molski court identified in rejecting the Allison test.

2. The problem of the future of "civil rights litigation" and "predominance"

The Molski court cited Robinson, noting that "such a bright-line rule holds troubling implications for the viability of future civil rights actions, particularly those under the Civil Rights Act of $1991 .{ }^{, 82}$ Rule 23(b)(2) was drafted with civil rights cases in mind actually. The Advisory Committee Notes for the rule first describes the general situations the rule is intended to reach. ${ }^{83}$ When a party has "taken action or refused to take action with respect to a class, and final relief of an injunctive nature or of a corresponding declaratory nature, settling the legality

\footnotetext{
${ }^{79}$ Id. at 950 (citing Robinson v. Metro-North, 267 F.3d 147, 163-64 (2001) (citing Allison, 151 F.3d at 430-31 (Dennis, J., dissenting))).

${ }^{80} 436$ F.2d 791 (10 $0^{\text {th }}$ Cir.1970).

${ }^{81}$ Though Gold Strike Stamp was a case involving 23(b)(3) certification, it seems that courts have extended it to apply to all 23(b) certification tests, as the Molski court does. See e.g. Bermudez v. Dept. of Agriculture, 490 F.2d 718 (U.S.App.D.C.1973).

${ }^{82}$ Id. at 950 (citing Robinson v. Metro-North, 267 F.3d 147, 165 (2001)).

${ }^{83}$ Notes of Advisory Committee on 1966 Amendments to Rules, Rule 26(b)(2), supra note 4.
} 
of the behavior with respect to the class a whole, is appropriate." ${ }^{\prime 44}$ The Advisory Committee Note goes on to point out that the subsection is "not limited to civil-rights cases." 85

Several scholars and writers have considered this language against the predominant damages language in the same Advisory Committee Note. ${ }^{86}$ When Allison came down, some commentary considered whether or not Title VII civil rights discrimination cases would be curbed. One writer noted the expansion of Title VII as contributing to the increase in such litigation and which led to the atmosphere in which Allison was decided. ${ }^{87}$ Though this expansion led to the bright-line approach of Allison, several civil procedure devices could be used to circumvent the test and still allow the class action claims to proceed. ${ }^{88}$

Professor Hart agrees that Allison des not destroy the viability of these cases, and instead "may increase the level of scrutiny and perhaps the level of judicial involvement necessary in an employment discrimination class action." ${ }^{, 89}$ This is not fatal, but it does raise questions of why hostility towards these class action suits are occurring and the use of "predominant" as the reason to bar such litigation. ${ }^{90}$ Perhaps it is the perception that class actions are generally unfair due to the prospect of judicial blackmail, ${ }^{91}$ or that anti-discrimination laws are no longer necessary because of the different landscape in the workplace today. ${ }^{92}$

Another analysis of the struggle between civil rights lawsuits centers on the use of the Advisory Committee Notes and the appropriate statutory construction of these principles. Natasha Dasani argues that the best interpretive approach for 23(b)(2) is to use a purposive

${ }^{84} I d$.

${ }^{85} \mathrm{Id}$.

${ }^{86}$ See supra I.A for discussion regarding this language.

${ }^{87}$ See Jordan, supra note 24, at 850-53 (noting the Civil Rights Act of 1991, the Pregnancy Discrimination Act of 1978 and the Equal Employment Commission have expanded Title VII).

${ }^{88} \mathrm{Id}$. at 846-67. Some of these approaches are discussed infra at III.C.

${ }^{89}$ Melissa Hart, Will Employment Discrimination Class Actions Survive, 37 AKRON L. REV. 813, 814 (2004).

${ }^{90} \mathrm{Id}$.

${ }^{91} I d$. at $835-41$.

${ }^{92}$ Id. at 841-44. 
approach, referring to the Advisory Committee Notes. ${ }^{93}$ The Robinson court's approach is a purposive one and would be better suited for Title VII cases, Dasani argues. ${ }^{94}$

These different arguments all suggest that there is a well-founded fear of an attack and eventual death of civil rights discrimination cases under Allison. The Molski court is caught up in this debate also, and with their approach, they attempt to satisfy these concerns with their test. "In order to determine predominance, we have focused on the language of Rule 23(b)(2) and the intent of the plaintiffs in bringing the suit." ${ }^{.95}$ The court considered the actions of Molski in bringing about the suit and inferred what the primary goal of the litigation and the settlement agreement was. ${ }^{96}$ Agreeing that the litigation was commenced for injunctive relief, the Molski court held that the district court did not abuse its discretion in it certification of the class.

The Molski approach here is perhaps the most flexible of the three approaches discussed in this Note thus far. It gives high discretion to the court and looks to the intent of the plaintiffs. In some ways this is a bright-line test of its own that allows the entire situation to be considered by the certifying court. This way, the court may consider both the public policy needs of civil rights as well as the need to adhere to the predominant-requirement of the Rule.

3. The problem of notice and opt-out revisited

The Molski court also considered a due process claim related to the notice and opt-out problems the other courts encountered. At the center of the issue were the appellants' claim that the relatively recent 1999 Supreme Court case of Ortiz v. Fibreboard ${ }^{97}$ required some due

\footnotetext{
${ }^{93}$ Dasani, supra note 65, at 205.

${ }^{94} I d$. at 202-05.

${ }^{95}$ Molski v. Gleich, 318 F.2d 937, 950 (9th Cir. 2003).

${ }^{96} \mathrm{Id}$.

${ }^{97} 527$ U.S. 815 (1999).
} 
process to allow for opt-out of absent members "if any monetary damages are involved." ${ }^{\text {98 }}$ The Molski court rejected the claim that the Ortiz rule was per se in nature and was to be applied in the instance; instead the court read the opinion as recognizing some limitations on protections for absent members. ${ }^{99}$ The Supreme Court had pointed to Phillips Petroleum v. Shutts, ${ }^{100}$ which had limited due process protections to only out-of-state class members for monetary judgments. ${ }^{101}$

The Molski court bolstered its position by noting that in some cases there had been mandatory certifications of a class even with the existence of money damages. ${ }^{102}$ Mandatory classes have appeared in various contexts, particularly the mass torts area ${ }^{103}$ Consequently, these mandatory certifications are an example that that the Ortiz case is not so much as a rule, but simply a case that had a desirable outcome for the appellant.

\section{Comparing the approaches}

The three approaches described in the Part describe the range of arguments and issues that all feed into the ultimate formulation of how to deal with the complex litigation arising out of civil rights discrimination class action cases. The Table below summarizes these concerns.

Table: Comparison of various issues between the three approaches

\begin{tabular}{|c|c|c|c|}
\hline & $\begin{array}{c}\text { Allison } \\
\text { (Leading approach) }\end{array}$ & $\begin{array}{l}\text { Robinson } \\
\left(2^{\text {nd }} \text { Cir. }\right)\end{array}$ & $\begin{array}{l}\text { Molski } \\
\left(9^{\text {th }} \text { Cir. }\right)\end{array}$ \\
\hline $\begin{array}{l}\text { Fed. Rule Reading: } \\
\text { Damages should flow } \\
\text { from the class as a } \\
\text { whole, rather than the } \\
\text { individual. }\end{array}$ & $\begin{array}{l}\text { Major concern discussed } \\
\text { by court here. }\end{array}$ & $\begin{array}{l}\text { Responds to Allison with } \\
\text { discussion that this is an } \\
\text { inflexible rule. }\end{array}$ & Adopts Robinson. \\
\hline $\begin{array}{l}\text { Judicial economy: } \\
\text { Calculation of damages } \\
\text { should not be permitted } \\
\text { for individuals }\end{array}$ & $\begin{array}{l}\text { Major concern discussed } \\
\text { by court here. }\end{array}$ & $\begin{array}{l}\text { Responds to Allison by } \\
\text { pointing out that this may } \\
\text { be done in the remedial } \\
\text { stage. }\end{array}$ & \\
\hline
\end{tabular}

\footnotetext{
${ }^{98}$ Molski v. Gleich, 318 F.2d 937, 948 (9th Cir. 2003) (emphasis court's own).

${ }^{99} \mathrm{Id}$.

100472 U.S. 797 (1985).

${ }^{101}$ Ortiz v. Fibreboard Corp., 527 U.S. 815, 848 n.24 (1999)

${ }^{102}$ Molski v. Gleich, 318 F.2d 937, 948 (9th Cir. 2003)

${ }^{103}$ See generally, Alba CONTE \& Herbert NeWBERG, NEWBERG ON Class Actions $§ 17: 40$ (4th ed. 2002).
} 


\begin{tabular}{|l|l|l|l|}
\hline & \multicolumn{1}{|c|}{$\begin{array}{c}\text { Allison } \\
\text { (Leading approach) }\end{array}$} & \multicolumn{1}{|c|}{$\begin{array}{c}\text { Robinson } \\
\left(\mathbf{2}^{\text {nd }} \text { Cir.) }\right.\end{array}$} & \multicolumn{1}{c|}{$\begin{array}{c}\text { Molski } \\
\left(\mathbf{9}^{\text {th }} \text { Cir.) }\right.\end{array}$} \\
\hline $\begin{array}{l}\text { Public policy: The need } \\
\text { for civil rights litigation } \\
\text { to proceed under } \\
\text { 23(b)(2) }\end{array}$ & \multicolumn{1}{|c|}{$\begin{array}{l}\text { Major concern discussed } \\
\text { by court here. }\end{array}$} & $\begin{array}{l}\text { Major concern discussed } \\
\text { by court here. }\end{array}$ \\
\hline $\begin{array}{l}\text { Courts' discretion: } \\
\text { bright-line approach } \\
\text { versus flexibility }\end{array}$ & $\begin{array}{l}\text { Prefers bright-line } \\
\text { approach to reduce risk of } \\
\text { due process harm. }\end{array}$ & $\begin{array}{l}\text { Discretion of court is } \\
\text { important, as a matter of } \\
\text { court's function. }\end{array}$ & $\begin{array}{l}\text { Discretion of court is } \\
\text { important, as a matter of } \\
\text { court's function. }\end{array}$ \\
\hline $\begin{array}{l}\text { Due process harm for } \\
\text { absent members }\end{array}$ & $\begin{array}{l}\text { Major concern discussed } \\
\text { by court here. }\end{array}$ & $\begin{array}{l}\text { Responds to Allison by } \\
\text { noting that notice may still } \\
\text { be ordered later. }\end{array}$ & \\
\hline Intent of parties & & & $\begin{array}{l}\text { Major concern discussed } \\
\text { by court here. }\end{array}$ \\
\hline
\end{tabular}

\section{Approaches to resolving the split}

\section{A. A widening-circuit split}

In the largely publicized case of Dukes v. Wal-Mart Stores, Inc., the Ninth Circuit applied the Molski test. ${ }^{104}$ The result was class certification of a large class action suit based on gender discrimination in promotion practices at the largest American employer. Dukes represents a consequence of the Allison circuit split: a strong incentive for forum shopping.

In the Dukes case, a class of women employees sued mega-national company Wal-Mart, which is the largest American employer in the private sector, as well as the largest employer in the world. ${ }^{105}$ The plaintiffs probably decided to bring suit in San Francisco in the Northern District of California because of the Molski approach. As a consequence, the Allison approach was circumvented easily and a form of forum shopping took place.

Admittedly, any of the civil rights discrimination cases discussed so far may have been brought under different means, but the straight 23(b)(2) certification is the preferred certification for such a large class of its type here in Dukes. Among the reasons are that there is an implicit preference for certification under Rule 23(b)(1) or (b)(2) because of the structure of the Rule as a

${ }_{104}^{104} 222$ F.R.D. 137, 171 (N.D.Cal. 2004).

${ }^{105} \mathrm{Id}$. at 141 . 
whole, though this is not articulated explicitly. ${ }^{106}$ There are fewer burdens on the party seeking certification due to notice and other $23(b)(3)$ requirements. ${ }^{107}$ Consequently, in deciding where to sue the largest employer that probably has substantial contacts with any jurisdiction within the United States, the plaintiffs in Dukes chose the Northern District of California, recognizing the ease in getting 23(b)(2) certification after Molski.

The reasons why forum shopping is disfavored are widely recognized: they create jurisdictional problems, inconsistencies in application as well as notice problems for claimants in jurisdictions that may have not approached the problem yet. ${ }^{108}$ This split coupled with the historic and unique nature of the Dukes case makes it ripe for Supreme Court review and also creates problems for other jurisdictions with the blatantly different approach. ${ }^{109}$

B. Balancing the competing goals of the Civil Rights Act of 1991 and the Class Certification under 23(b)(2)

Class action suits provide tangible benefits to the judicial system. For plaintiffs similarly situated, the costs for hiring an attorney, the costs of discovery, production of documents and litigating each individual case presents a high transaction cost. In a Coaseian economic consideration, justice would be best administered and managed if these transaction costs are reduced. ${ }^{110}$

\footnotetext{
${ }^{106}$ Newberg, supra at 103, §4:20.

107 Id.

${ }^{108}$ But see Bianco v. Erikins, 243 F.3d 599, 606 (noting the "mere desire for uniformity and the prospect of forum shopping as insufficient for federal interests").

${ }^{109}$ Robert Fisher, Dukes v. Wal-Mart: Can 1.5 Million Women Save Employment Discrimination Class Actions?, 12 CARDOZO J. L. \& GENDER 1009 (2006).

${ }^{110}$ See generally Ronald Coase, The Problem of Social Cost, 3 J. L. \& ECON. 1 (1960). The Coase Theorem, simply stated, is that in a system with transaction costs, individuals will bargain amongst themselves to achieve the most economic outcomes. The corollary here is that class action suits will occur at such bargained lower cost regimes through devices such as forum shopping or creating an alternative litigation strategy.
} 
Procedure is important in the outcome of a case particularly large complex cases, despite what the idealists would say. ${ }^{111}$ The goal of class action suits is to allow economy of administration of justice, bringing about widespread change quickly and efficiently. ${ }^{112}$

The goal of 23(b)(2) was to handle civil rights discrimination case. ${ }^{113}$ But it tried to limit the application of the Rule, trying to restrict cases in which more than just injunctive relief was sought for the primary purpose. ${ }^{114}$ These two competing goals run against each other in this existing circuit split issue. If the case that a class of plaintiffs brings to court is really about discriminatory practices that a company is engaging in, then the "real" goal for the plaintiffs is about changing the allegedly discriminatory practices and not focused on getting a large monetary judgment necessarily. The nature and type of discriminatory practice however may have monetary elements built in. For instance, if an alleged discriminatory act is about low wages, then the back pay to make up for the discriminatory practice is necessarily monetary. Even the Allison court agreed that these damages would survive the incidental damages test. ${ }^{115}$

Gray areas exist in assessing the dichotomy between monetary-focused intentions and purely injunctive-focused remedies. Promotion practices are an example. In Dukes, the plaintiffs' lawyers have made it clear that it is the discriminatory practice of a glass ceiling that is keeping women from higher positions within the company. ${ }^{116}$ Though the Ninth Circuit eventually granted certification for the 1.5 million women that have worked at Wal-Mart, it begs the question of whether the class would have been certified under an Allison approach. There is a

\footnotetext{
${ }^{111}$ See generally Richard Marcus, Reassessing the Magnetic Pull of Megacases on Procedure, 51 DEPAUL L. REV. 457 (2001).

${ }^{112}$ Stephen C. Yeazell, From Medieval Group Litigation to the Modern Class Action 8-9 (1987).

${ }^{113}$ See Dasani, supra note 65, 194-98.

${ }^{114} I d$.

${ }^{115}$ Supra II.A.

${ }^{116}$ Dukes v. Walmart, 222 F.R.D. 137, 142.
} 
monetary component in promotion practices technically; the eventual promotion to a new category of pay by its very nature is monetary.

Using the Allison bright-line approach would create judicial economy and certainly resolve the gray easily, but it can have the consequence of barring any Title VII claim when monetary damages are sought. In a recent Sixth Circuit case involving female prison guards attempting to sue as a class for gender discrimination in promotion, leave, discipline and other employment factors, the Allison standard was applied and the classification was denied. ${ }^{117}$ Judge Alice Batchelder wrote, "Title VII cases in which plaintiffs seek individual compensatory damages are not appropriately brought as class actions under Rule 23(b)(2) because such individual claims for money damages will always predominate over requested injunctive or declaratory relief."118

Judge Damon Keith dissented vigorously, saying that this characterization by the majority was inappropriate and would curtail "the relief available to Title VII plaintiffs." 119 He expressed the concern that this was a complete bar for certification of any class with respect to this type of discrimination in the future. ${ }^{120}$ He pointed to Congress as the final arbiter to resolve the issue, decrying the Sixth Circuit from giving its ruling. ${ }^{121}$

\section{Alternative litigation approaches}

Class action suits are by their very nature complex entities that may be affected rather easily by procedural nuances. For instance, one approach is to try to bifurcate the class action

\footnotetext{
${ }^{117}$ Reeb v. Ohio Dept. of Rehabilitation and Corrections, 435 F.3d 639 (6th Cir. 2006).

${ }^{118} \mathrm{Id}$. at 641 .

${ }^{119} \mathrm{Id}$. at 660 .

${ }^{120} \mathrm{Id}$.

${ }^{121} I d$.
} 
into two parts - certifying the damages issues under Rule 23(b)(3) and anything remaining under $23(b)(2) .^{122}$

\section{Towards a Solution}

\section{A. An Unresolvable Tension}

The competing interests between the Civil Rights Act of 1991 and Rules 23(b)(2) are not reconcilable on its face. The ultimate solution is to revise the rules themselves. The revision would be to give some sort of explicit delineation or approach to be applied in the case of a 23(b)(2) certification attempt. But, in the absence of such a revision, courts may still adopt a judicial approach that will resolve the circuit split.

As early as 1986, before the 1991 amendments to the Civil Rights Act allowing monetary damages for civil rights discrimination in such lawsuits, litigation experts recognized Rule 23(b)(2)'s problem of certification noting "cases involving claims for both money damages and injunctive or declaratory relief present significant difficulties of classification."

\section{B. A heightened pleading framework}

Title VII discrimination cases currently follow a burden-shifting framework to prove disparate-treatment discrimination in the employment setting. The framework is based off of McDonnell Douglas Corp. v. Green ${ }^{124}$. This seminal case outlines a three stage process for establishing the discrimination cause of action that balances the interests of the various parties involved. Initially the plaintiff must meet a set of prima facie elements that facially indicates

\footnotetext{
122 Jordan, supra note 24 , at 873.

${ }^{123}$ ABA Sec. of Lit., Report and Recommendations of the Special Committee on Class Action Improvements, 110 F.R.D. 195, 197 (1986).

${ }^{124} 411$ U.S. 792,802 (1973).
} 
discrimination took place. ${ }^{125}$ Then, the defendant has the opportunity to rebut the elements by claiming defenses, excuses or disputing the plaintiff's case. ${ }^{126}$ Finally, the plaintiffs may rebut by showing that the defendant's claims are pretextual.

The benefits of this approach have been noted in the resulting notice to potential plaintiffs; now they are able to know from the outset of litigation before proceeding to a court that they have a case that needs to be rebutted by their defendants.

A criticism of this approach may be that heightened scrutiny at an earlier stage for some plaintiffs may preclude their ability to litigate. If there are limited monetary resources for the defendant, then they may not be able to pursue their case at such an early stage, particularly if there is a chance that they may succeed. A possible framework that models on McDonnell Douglas to relieve this criticism is to require plaintiffs to make a prima facie showing at the outset that their class action suit is truly seeking injunctive relief. This is reminiscent of the Ninth Circuit's approach. To show this, the following elements must be produced at the certification phase: (1) no reasonable potential class member would wish to be excluded and (2) the intent of the plaintiffs is to seek a change to company practice or policy.

1. Objective prong: No reasonable potential class member would wish to be excluded

Ostensibly, all the plaintiff would need to need show would be evidence that supports this. As with any objective test, the allegation by the plaintiff would be subject to the court's review. Examples of evidence that may be brought to meet this prong, may be depositions of a large

\footnotetext{
${ }^{125} I d$. (1) he or she belongs to a racial minority; (2) he or she applied and was qualified for a job for which the employer was seeking applicants; (3) he or she was rejected for the position despite his or her qualifications; and (4) the position remained open after his or her rejection and the employer continued to seek applications from other people with similar qualifications to the plaintiff.

${ }^{126}$ Some critics of this framework note that at this point, if the defendant is able to meet this rebuttal by meeting the burden of production, the plaintiffs win; the underlying case of an employer's intention of discrimination has never even been considered. E.g. Charles A. Sullivan, Disparate Impact: Looking Past the Desert Palace Mirage, 47 W\&M. L. REV 911, n.62 (2005).
} 
number of plaintiffs, substantially similar past suits, or the particular nature of the situation and the suit. The district court would use its own discretion in considering the presented evidence, and it would be subject to review on appeal, as any such question may be.

There are of course situations in which a "reasonable" class member may wish to opt-out of a class action suit. In Molski, some members sought to opt out because they did not like the initial consent decree or the injunctive declaration. ${ }^{127}$ This makes the test more difficult to apply, but the test is objective in nature and over time, case law would develop what "reasonable" means.

\section{Subjective prong: The intent of the plaintiffs}

This element is the Molski court's approach. Therefore, the same application would be appropriate here. The test is an expression of what all the approaches arguably are doing, though some purport to do so with a bright-line approach, while others use a totality of the circumstances approach. This prong is completely subjective and a court would assess the intent of the class representative on direct examination. The opposing party would be able to rebut and cross-examine as appropriate to challenge the intent of the plaintiffs.

In order to prevail on 23(b)(2) certification then, the class representative would need to survive examination from the court, showing the intent of the litigation is not purely for money and instead is for the righting of civil rights discrimination in the form of injunctive relief. Of course, questions arise over what is "purely for money." This is just the "predominant" test in a different form. But the difference here is that the court is able to use its discretion in determining what predominant is, rather than having to use the Allison approach of considering if there is the need for individual calculation of damages for each plaintiff.

${ }^{127}$ Molski v. Gleich, 318 F.2d 937, 942 (9th Cir. 2003). 


\section{Benefits of the proposed approach}

This test is a combination of the Molski approach of assessing the plaintiff's intent. But it is also balanced by an objective test of reasonableness that reflects the concerns of due process in notice and opt-out as articulated by the various courts. The test is also conjunctive in nature and clear in the requirements. This would provide advance notice to potential litigants what is required to get in the door of the courthouse; consequently, there is a prescreening of these cases and some judicial efficiency is accommodated, directly addressing that issue.

The test does ignore the Allison test of trying to assess how and where the damages are to flow from. This is intentional. As noted in the Reeb case, the consequence of any sort of employment case can have monetary damages sought. Trying to draw a line between what is predominant for the relief sought is an impossible task and would only cause frustrations and impossibility of application. ${ }^{128}$

\section{Problems of the proposed approach}

1. Heightened pleading at too early a stage in litigation

One potential criticism is that the approach would go against a recent Supreme Court decision, in that the approach would actually be a form of heightened pleading at an early stage. In Swierkiewicz v. Sorema, ${ }^{129}$ a Hungarian native sued his employer, a reinsurance company headquartered in New York for national origin discrimination. ${ }^{130}$ Suing under the Civil Rights Act as well as the Age Discrimination in Employment Act of 1967(ADEA), ${ }^{131}$ the plaintiff's case was dismissed at the trial court level for not adequately alleging a prima facie case. ${ }^{132}$ The

\footnotetext{
${ }^{128}$ The proper solution is to amend the Federal Rules of Civil Procedure. This may not be done by judicial review, but must be properly amended.

${ }^{129} 534$ U.S. 506 (2002).

${ }^{130} \mathrm{Id}$. at 508 .

${ }^{131} 81$ Stat. 602, as amended, 29 U.S.C. $\$ 621$ et seq.

${ }^{132}$ Swierkiewicz v. Sorema, 534 U.S. 506, 509 (2002).
} 
United States Court of Appeals for the Second Circuit affirmed the precedent. ${ }^{133}$ At this point, a circuit split had developed over the question of whether or not there needed to be complete pleading at the complaint stage of an employment discrimination case. ${ }^{134}$ The Supreme Court decided to take the case, in the end reversing the lower courts and that in Swierkiewicz's case, the requirements of Federal Rules of Civil Procedure 8(a)'s ${ }^{135}$ claim for relief was satisfied. Heightened specificity at the pleading stage can only be obtained by the process of amending the Federal Rules, and not through the process of judicial interpretation. ${ }^{136}$

The proposed test in this case would not be a problem with Swierkiewicz, however, because the question is about certification of the class and not the prima facie elements of the case. The elements presented all deal with certification, and if denied, the plaintiff is not barred from pursuing certification under any of the other 23(b) categories or pursuing one of the alternative litigation strategies.

\section{Rule 23(a) gatekeeper concerns}

By considering subjective intent of the class representative, then there may be a problem with a certifiable class, under the gatekeeper test of Rule 23(a), specifically the typicality factor. ${ }^{137}$ In Dukes, the court considered the intent of the class representative as well as the plaintiff's lawyers; ${ }^{138}$ there was no attempt to assess what the 1.5 million women named in the complaint were, and instead an assumption was made that typicality would not be problematic.

\footnotetext{
${ }^{133} \mathrm{Id}$.

${ }^{134} \mathrm{Id}$.

${ }^{135}$ Fed. R. Civ. Proc. 8(a) states that "a pleading ... shall contain ... (2) a short and plain statement of the claim showing that the pleader is entitled to relief .... Relief in the alternative or of several different types may be demanded."

${ }^{136}$ Leatherman v. Tarrant County Narcotics Intelligence and Coordination Unit, 507 U.S. 163, 168 (1993).

${ }^{137}$ NEWBERG, $\$ 3: 14$.

${ }^{138}$ Dukes v. Walmart, 222 F.R.D. 137, 142.
} 


\section{The chilling effect on civil rights litigation}

Admittedly this proposal may result in fewer civil rights discrimination cases, due to a higher standard. Though this is unfortunate from a public policy perspective, this Note articulates this approach because of the legal consequences of an inconsistency created by the conflicting language of the Civil Rights Act of 1991 and Rule 23(b)(2). Instead of disregarding the language of Rule 23(b)(2) which is fairly clear, this approach seeks to adhere to it still. The best change of course is to revise the language of both legal instruments.

\section{Conclusion}

This Note has presented the difficulties of the existing circuit split over class certification of civil rights discrimination cases. It proposes a solution that would work within the existing system. The dominant approach of Allison creates too high a hurdle for the success of the original intent of 23(b)(2) certification. The underlying needs to ameliorate civil rights problems should be a central factor in resolving the split.

Though the resulting solution proposed in this note chooses in the end to favor a legal solution to the questions at hand, it is important to still realize that this favoring discounts the Congressional intent of allowing civil rights employment discrimination to be litigated under 23(b)(2). Though there is opportunity even after denial of certification under 23(b)(2), the encumberances of certification under either $23(b)(1)$ or (b)(3) would have an even further chilling effect upon potential class action suits seeking to remedy civil rights discrimination. This result stands legally, but is against public policy interests for providing a tool to the encumbered to combat workplace discrimination; the best solution is for Congress to clear up the confusion by amending the Civil Rights Act or the Supreme Court along with Congress to resolve what the standard for 23(b)(2) certification should be in the language of the predominant damages test. 